\title{
The Origin and Development of Pongee in Shandong in Modern China
}

\author{
Tianyi Song ${ }^{1} \&$ Xiangyang Bian ${ }^{1}$ \\ ${ }^{1}$ College of Fashion and Design, Donghua University, Shanghai, China \\ Correspondence: Song Tianyi. E-mail: songty1990@163.com
}

Received: December 1, 2021

Accepted: December 8, 2021

Online Published: February 28, 2022

doi:10.5539/ass.v18n3p21

URL: https://doi.org/10.5539/ass.v18n3p21

\begin{abstract}
Pongee, also known as Shantung, originated and developed in Shandong, China is already a consensus in the academic community; China's modern era (late 19th century to the 1940s) is the golden period of pongee development, the influence of this period shantung all over the world. However, the origin and development of pongee in Shandong Province, the reasons for the current very few scholars to study. The article from the natural, historical, political, economic, and cultural perspectives explore the reasons for its origin in Shandong, summarizing the suitable geography, climate, reeling silk weaving a long history, the Qing Dynasty government and Shandong officials actively promote sericulture and pongee weaving technology; Shandong intellectuals compiled sericulture books, as well as manual silk weaving to supplement the small farmer economy, the opening of international trade along the coast of Shandong and other reasons. These factors are indispensable and interact, ultimately leading to the emergence and development of pongee in Shandong.
\end{abstract}

Keywords: Modern China (1840-1949), Shandong, Pongee, origin, development

As early as the Qing Dynasty painter Xu Yang painted in the Qianlong twenty-fourth year (1759) of the "Shengshi Zisheng" can be seen on the silk store hanging on the obvious plaque on the book "Shandong Yishui pongee hair customers do not neglect," it can be seen as early as the early Qing Dynasty Shandong pongee is famous nationwide. At present, the global academic community on the origin and rise of pongee in Shandong, China, has reached a consensus, which can be seen from the pongee named "Shantung," but the reasons for the prosperity in Shandong at present no professional papers to summarize. And the literature exists more in the ancient Chinese books, which puts a high demand on the translation work. Modern times is the development of pongee golden period, pongee from Shandong region is not accidental, nor is it a single factor to decide, it is by the natural, political, economic, cultural, historical and other factors under the multiple role of the production, each factor is indispensable, the interaction.

\section{Natural Factors}

Pongee as a natural material woven fabric, Shandong region has the natural conditions consistent with its raw material output, which is the most fundamental factor. Shandong is located at 34 degrees -38 degrees north latitude, belongs to the mid-latitude region, Shandong central mountainous prominence, the eastern gentle rolling hills, the terrain is dominated by mountain hills, the eastern part is the Shandong Peninsula, the western and northern part of the North China Plain, the central and southern part of the mountain hills, the formation of mountain hills as the skeleton, plains and basins interlaced between the landforms. The average annual temperature is $11^{\circ} \mathrm{C}-14^{\circ} \mathrm{C}$, and the frost-free period increases from the northeast coast to the southwest, generally 180 days in the north and Jiaodong, and up to 220 days in the southwest of Lu. Light resources are abundant, with an annual average of 2290-2890 hours of light, and the average annual precipitation is generally between $550-950 \mathrm{~mm}$, which is a warm temperate monsoon climate. The hills of Shandong are gently undulating, the gullies are crisscrossed, and the suitable temperature is suitable for the growth of Quercus and the rearing of Quercus silkworms. 


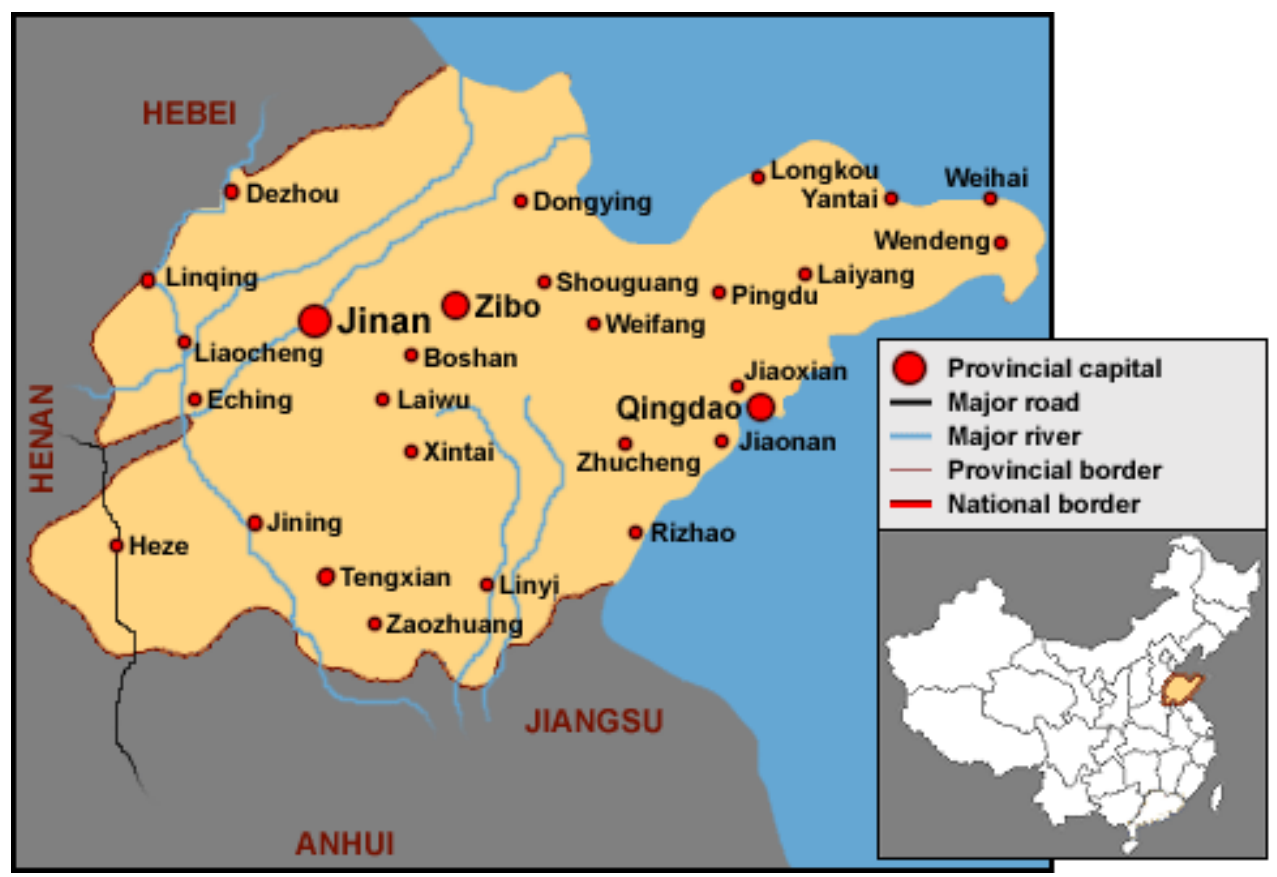

Figure 1. Map of Shandong Province, China

\section{Historical and Cultural Factors}

Shandong is one of the important birthplaces of silk since ancient times, "Hanshu. Geography," there are clouds: "Lu land narrow people, quite a mulberry industry," "Qi weaving ice froth embroidered pure and beautiful things, called the crown and clothing over the world"1. As early as the Qin and Han dynasties, Linzi has a special clothing for the emperor's "three clothing officer", Shandong is the center of China's silk weaving industry before the Tang and Song dynasties, with a long history. In addition, Shandong is also one of the important sources of the Silk Road, Shandong as the land Silk Road and the northern intersection of the Maritime Silk Road, as early as "Zhang Qian chiseling" before, Shandong silk through the land and sea Silk Road to the west to Central Asia, West Asia, to the east to the Japanese Islands, the Korean Peninsula, and other places. Ancient Shandong silk was exchanged overseas mainly through three ways: first, foreign rewards, diplomatic activities directly to the West and overseas countries; second, for the military, mutual markets through the Silk Road to the northwest, Central Asia, West Asia, Europe, or Japan and Korea; third, the internal currency payments into the market, followed by trade activities flowing overseas. Along the Silk Road in Gansu Weiwu Tang Zui Zi unearthed Linzi three clothes official production lacquer kerchief crown, Gaochang unearthed the Han Dynasty Qingzhou Chidi, and other textile archaeological discoveries have confirmed the fact that Shandong silk foreign exchange. Qingzhou Fujiazhuang Northern Qi line engraved portrait stone on the trade map, the master and servant conversation map, the elephant map, and other archaeological findings on the record of Shandong merchants with the Western silk trade scenes, and Qingzhou Buddhist statues of the North and South Dynasties period in the shiny square mouth shoes and Hu figures. India after the local transformation and spread to Japan and other countries, "Qingzhou Buddha statue The artistic style of "Qingzhou Buddha statue" and so on prove that Shandong had not only frequent trade with Central Asia, West Asia, East Asia, and other regions before the Tang Dynasty but also had rich cultural exchanges.

In the thousands of years of Chinese culture nurtured and formed, raising silkworms, reeling silk, and weaving silk became the daily life of the people of Qilu and an important vehicle for the epitome and spread of Qilu culture.

\section{Political Factors}

The first and middle of the Qing dynasty is the first pongee period, especially in the Kangxi, Yongzheng, Qianlong three dynasties, Shandong long-term social stability, economic prosperity, although the end of the Qing dynasty China into a stormy semi-colonial semi-feudal society, but the pre-stable social environment to pongee has laid the foundation for the production.

In the cause of silk weaving pongee, the local government of Shandong in the Qing Dynasty has adhered to the 
attitude of support, tax relief, and actively promoting the release of silkworms. According to the "Qing dynasty history manuscript notes": during the Qianlong period, the then governor of Shandong Altai "to produce mountain silk in Shandong, sparse request for the private sector on the slopes of the gap to plant a wide range of quince, exempt from its promotion." ${ }^{2}$ The word "exempted from the promotion of science" means "exempted from collecting taxes." During the Qianlong period, Li Hu, the governor of Ninghai, Shandong Province, persuaded the villagers to raise quince silkworms and weave silk, and the farmers were grateful for their contribution and "have been benefited by them, so they set up a shrine to worship them." ${ }^{3}$ Due to the support of the local government of Shandong in modern times, many places in Shandong were widely planted with Quercus sericea, and the technology of artificially rearing Quercus sericea was promoted rapidly. With the progress and improvement of weaving technology, silk and silk were produced together by the middle of the Qing Dynasty. At the end of the Qing Dynasty, the Qing government implemented a short-lived "New Deal." However, this "New Deal" was carried out by the Qing government to consolidate its feudal rule. Still, the sericulture silk and pongee industry seized this short-lived opportunity, and its price rose for several years. The economic benefits of sericulture households and weavers, and silk merchants increased. The economic benefits of silk merchants increased, which also directly promoted the development of the mechanization of the silk reeling and silk weaving industry along the coast of Shandong.

The local government of Shandong not only promoted the technology of releasing silkworms and weaving silk to the province, but also the Shandong officials who were active in the WTO introduced this industry that could improve people's livelihood to many provinces in the mainland. In his paper, "An Examination of the Origin and Spread of Sericulture in China," Zhang Kai mentions, "Most of the local officials who advocated sericulture were of Shandong origin ......" ${ }^{4}$ The officials of Shandong nationality who served in foreign provinces spread the sericulture technology of their homeland to the places where they did, which not only created a new cash crop for the local area but also increased the income of the local farmers. Shandong officials who spread sericulture artificial stocking technology to foreign provinces in the Qing Dynasty are as follows.

Table 1. Statistics of Shandong officials who spread the artificial rearing technology of sericulture to other provinces during the Qing Dynasty

\begin{tabular}{|c|c|c|c|}
\hline Name & Place of origin & Place of employment and position & Deeds \\
\hline Liu Qi & $\begin{array}{l}\text { Shandong } \\
\text { Zhucheng }\end{array}$ & $\begin{array}{c}\text { He was the governor of } \\
\text { Ningqiang Prefecture in Shaanxi } \\
\text { Province }\end{array}$ & $\begin{array}{l}\text { In } 1698 \text {, he was the first person to } \\
\text { introduce the technique of sericulture to } \\
\text { Shaanxi. }\end{array}$ \\
\hline Hao Jingxiu & $\begin{array}{l}\text { Gao Mi, } \\
\text { Shandong }\end{array}$ & $\begin{array}{l}\text { Governor of Hanyin County, } \\
\text { Shaanxi Province. }\end{array}$ & $\begin{array}{l}\text { In } 1771 \text {, he promoted the sericulture in } \\
\text { Hanyin County. }\end{array}$ \\
\hline Wang Jun & $\begin{array}{l}\text { Shandong } \\
\text { Jiaozhou }\end{array}$ & $\begin{array}{l}\text { Governor of Dayi County, } \\
\text { Sichuan }\end{array}$ & $\begin{array}{c}\text { In the fifth year of Qianlong (1740), he } \\
\text { was the first to spread the sericulture } \\
\text { technology from the sericulture to } \\
\text { Sichuan. }\end{array}$ \\
\hline An Hongde & $\begin{array}{l}\text { Liaocheng, } \\
\text { Shandong }\end{array}$ & $\begin{array}{l}\text { Governor of Mianzhu County, } \\
\text { Sichuan. }\end{array}$ & $\begin{array}{l}\text { Around } 1740 \text {, he taught people to raise } \\
\text { sericulture in Mianzhu County. }\end{array}$ \\
\hline $\begin{array}{l}\text { Wang } \\
\text { Haoxu }\end{array}$ & $\begin{array}{l}\text { Qingzhou, } \\
\text { Shandong. }\end{array}$ & $\begin{array}{l}\text { Governor of Fengdu County, } \\
\text { Sichuan. }\end{array}$ & $\begin{array}{l}\text { In } 1757 \text {, he taught people to raise } \\
\text { sericulture in Fengdu County. }\end{array}$ \\
\hline Chen Yubi & $\begin{array}{l}\text { Licheng, } \\
\text { Shandong } \\
\text { Province }\end{array}$ & $\begin{array}{c}\text { Governor of Zunyi Prefecture, } \\
\text { Guizhou }\end{array}$ & $\begin{array}{l}\text { In } 1738 \text {, he was the first to introduce the } \\
\text { technique of sericulture to Guizhou. }\end{array}$ \\
\hline .Han Litang & $\begin{array}{l}\text { Weixian, } \\
\text { Shandong }\end{array}$ & $\begin{array}{c}\text { Governor of Lai'an County, } \\
\text { Anhui Province }\end{array}$ & $\begin{array}{l}\text { In the thirty-first year of the Qianlong } \\
\text { reign (1766), he taught people to raise } \\
\text { sericulture in Lai'an County. }\end{array}$ \\
\hline Wu Guan & $\begin{array}{l}\text { Jinan, } \\
\text { Shandong }\end{array}$ & $\begin{array}{l}\text { Governor of Pingshun County, } \\
\text { Shanxi Province }\end{array}$ & $\begin{array}{l}\text { During the reign of Shunzhi, he } \\
\text { transplanted sericulture seeds to the } \\
\text { Taihang Mountains and taught the people } \\
\text { how to reel and reel. }\end{array}$ \\
\hline
\end{tabular}

In addition to the promotion of Shandong officials, intellectuals in Shandong will release the successful 
experience of silk weaving silkworms compiled into a sericulture book to promote the country. During the Qianlong period, the governor of Shandong was ordered by the imperial court to compile and send to the provinces a sericulture book called "The Method of Raising Mountain Silkworms," which was about the introduction of the method of artificially rearing sericulture in Shandong, the earliest known book on sericulture. The other widely known sericulture book "Wild Silkworm Record" is Ninghai state Dahe Dong village people Wang Yuan braided, his hometown ShanXiShanDuo mountain area is Ninghai state pongee industry is an important area, he is the GuangXu Wuxu (1898), high school scholar, after serving in Anhui SheXian County, and its according to what they saw and heard, in GuangXu non-Yin year (1902) compiled the "Wild Silkworm Record" to introduce and promote silk weaving technology. The book is illustrated with detailed descriptions of sericulture, sericulture rearing, silk reeling, weaving techniques, and various tools and is a valuable tool. Since then, officials or intellectuals in Shaanxi, Guizhou, Anhui, and Liaoning have published local sericulture books and texts based on the one compiled by Shandong. For example, during the Qianlong period, Chen Hongmou, the governor of Shaanxi Province, received the "Method of Raising Mountain Silkworms" and adapted the "Diatribe on Broadening Mountain Silkworms" to further promote sericulture; Han Mengzhou, the governor of Lai'an, Anhui Province, also compiled the "Method of Raising Silkworms" based on the "Method of Raising Mountain Silkworms," which is more popular and easy to understand. The articles and books related to sericulture written by Shandong intellectuals in the Qing Dynasty are summarized.

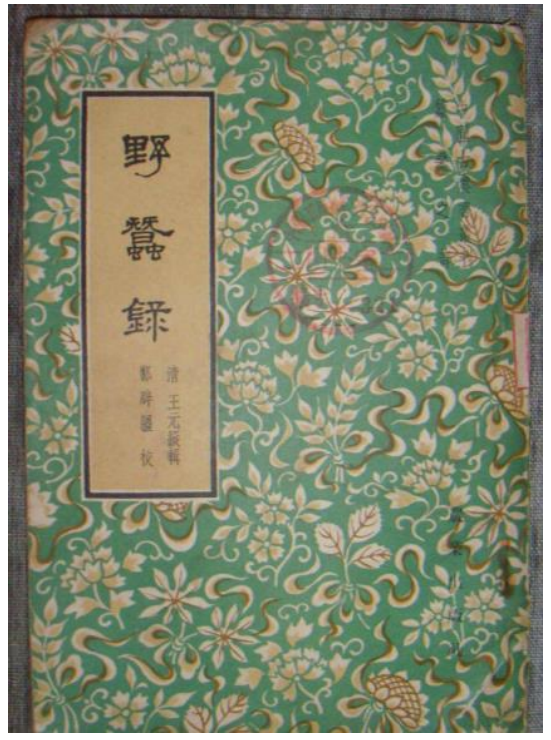

Figure 2. The Record of the Wild Silkworm

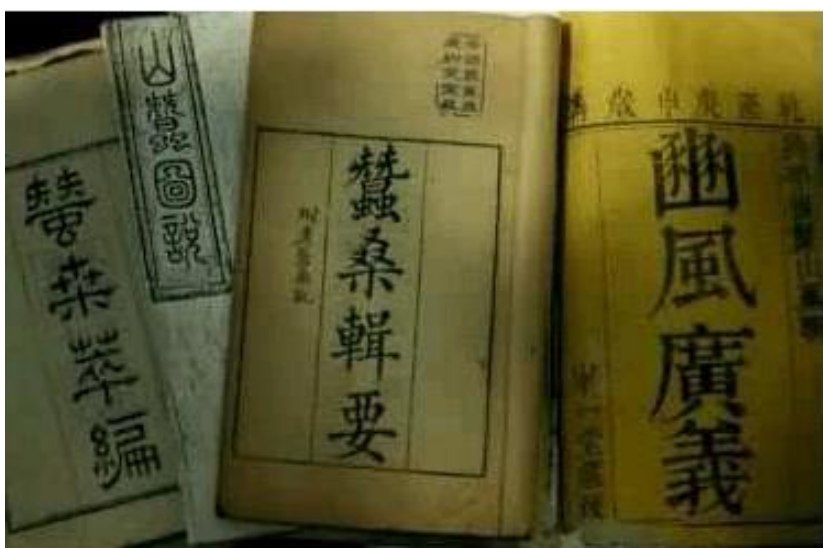

Figure 3. Ancient Chinese agricultural books about raising tussah and weaving pongee

Table 2. Statistics of articles and books related to sericulture written by intellectuals in Shandong during the Qing Dynasty ${ }^{5}$

\begin{tabular}{|c|c|c|c|}
\hline Name & Ancestry & Date of writing & Name of the text \\
\hline Sun Yanquan & $\begin{array}{l}\text { Yidu County, Qingzhou Prefecture } \\
\text { (present-day Qingzhou City) }\end{array}$ & $\begin{array}{l}\text { Shunzhi eight years } \\
\qquad(1651)\end{array}$ & $\begin{array}{l}\text { The saying of the silkworm in the } \\
\text { mountains and the silkworm in } \\
\text { Shandong (Note: the two books } \\
\text { are two book`s name in one) }\end{array}$ \\
\hline $\begin{array}{l}\text { Wang } \\
\text { Shizhen }\end{array}$ & $\begin{array}{c}\text { Xincheng (now Huantai County, } \\
\text { Zibo City) }\end{array}$ & $\begin{array}{c}\text { Shunzhi and Kangxi } \\
\text { years }\end{array}$ & $\begin{array}{c}\text { The Four Songs of the Mountain } \\
\text { Silkworm }\end{array}$ \\
\hline Zhang Song & $\begin{array}{c}\text { Zeshang Village, Wuji Town, } \\
\text { Ninghai Prefecture (present-day } \\
\text { Yantai Yushan City) }\end{array}$ & $\begin{array}{l}\text { During the } \\
\text { Yongzheng period } \\
\text { (around 1720). }\end{array}$ & $\begin{array}{c}\text { The Genealogy of the Mountain } \\
\text { Silkworm }\end{array}$ \\
\hline Wang Peixun & $\begin{array}{l}\text { Zhucheng County, Qingzhou } \\
\text { Prefecture (now Zhucheng City, } \\
\text { Weifang) }\end{array}$ & $\begin{array}{l}\text { During the Kangxi } \\
\text { period }\end{array}$ & The Mountain Silkworm Book \\
\hline
\end{tabular}




\begin{tabular}{|c|c|c|c|}
\hline Wang Haoxu. & $\begin{array}{c}\text { Qingzhou Prefecture, Zhucheng } \\
\text { County (now Weifang Zhucheng } \\
\text { City). }\end{array}$ & $\begin{array}{l}\text { Qianlong period } \\
\text { (around 1757) }\end{array}$ & $\begin{array}{c}\text { The Silkworm's Sayings and the } \\
\text { Rites of Feng }\end{array}$ \\
\hline $\begin{array}{c}\text { Han } \\
\text { Mengzhou }\end{array}$ & $\begin{array}{l}\text { Weifang County (now Weifang } \\
\text { City) }\end{array}$ & $\begin{array}{l}\text { Qianlong period } \\
\text { (between } 1766 \text { and } \\
1770 \text { ) }\end{array}$ & $\begin{array}{l}\text { The Law of Silkworm Breeding } \\
\text { and the Essay on Advising } \\
\text { Silkworm Breeding }\end{array}$ \\
\hline $\begin{array}{l}\text { Wang } \\
\text { Yuanwei }\end{array}$ & $\begin{array}{c}\text { Ninghai Prefecture, South of } \\
\text { Dahedong Village (now Muping } \\
\text { District, Yantai City). }\end{array}$ & $\begin{array}{l}\text { Guangxu Thirty } \\
\text { Years } 1902 .\end{array}$ & The Record of the Wild Silkworm \\
\hline
\end{tabular}

In the Republican period, Shandong published more great books on sericulture, such as Sun Zhong Dan's "Mountain Silkworm Series" and so on. Silk weaving technology from Shandong in the Qing Dynasty spread outward, which is directly related to the government's strong advocacy in the mid-and late-Qing period, but also a conscious administrative initiative of the elite intellectuals of Shandong origin in the field to serve in the policy of governance. ${ }^{6}$

\section{Economic Factors}

Since the Qing Dynasty, Shandong's rapid population growth, the contradiction between man and land is increasingly prominent; in order to meet the needs of life, the use of mountain hills gradually increased. However, the release of mountain sericulture requires labor, but compared with the family, sericulture is labor-saving and profitable. Regardless of the hills, mountains, as long as the trees can be planted, sericulture can be, without taking up arable land can be very profitable, so the Qing Dynasty was very rapid development. ${ }^{7}$ Early Qing Dynasty poet Wu Weiye wrote in his "Night stay in Meng Yin": "Wild silkworms are cocooned, and village wine is sold for no money." ${ }^{8}$ Qing Qianlong, Jiajing years, "the year out of the cocoon mountain silk without counting, Western customers are coming to sell, set up brokers to draw taxes, the annual income tax thousands of gold." Is also, pongee brings considerable economic benefits to the portrait. During the Qianlong period of the Qing Dynasty, Han Meng Zhou in the "sericulture into the law" on the pongee industry in Shandong's economic status of farmers to do a full explanation. "This silk woven by the silkworms called the mountain silk. Each silkworm a mu, you can get fifty to sixty nearly, seventy to eighty pounds vary. Shandong Province everywhere sericulture, the proverb 'a mu of silkworms, ten mu of fields', you can see that the actual profit." ${ }^{9}$ Lower production costs, coupled with higher profits, making the main reason for the rise of the cocoon and silk industry.

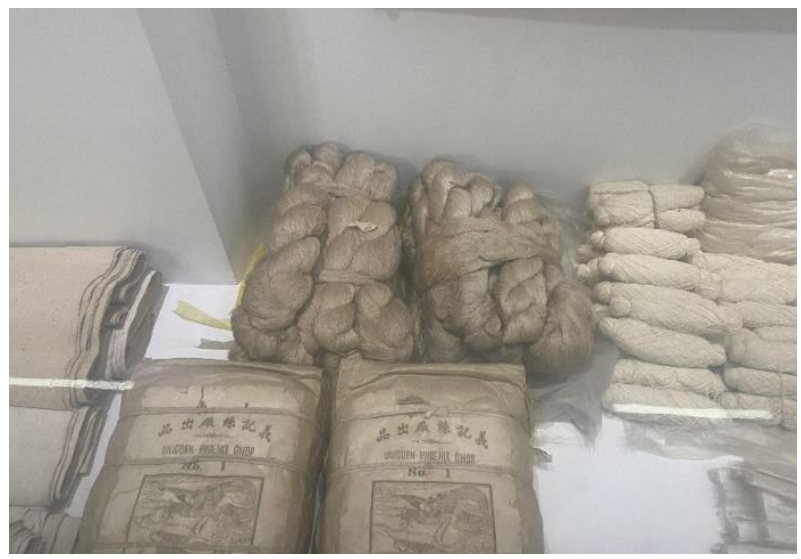

Figure 4. Tussah silk and pongee exported from Shandong during the Republic of China

Although, to the end of the Qing Dynasty, political peril, society began to become turbulent, the invasion of imperialism forced China into the international trade market, which in a sense on the cocoon and silk exports and to make a name for themselves overseas played a role. Shandong east to the west and the Central Plains hinterland, east of the Yellow and the Bohai Sea, north to Beijing, Tianjin and Hebei, the south can be linked to the southeast coastal provinces through the Grand Canal, land and sea, the area also has the Jiaoji Railway and other trunk lines, sea, and land transportation advantages make the coast of Shandong become one of the first to open ports. From the early Qing Dynasty to the middle of the 19th century, especially after the opening of Yantai 
and Qingdao, Shandong merchants gathered a high degree of capital distribution. They concentrated in areas roughly along with the canal towns, Jiaodong Jinlai area, and Jiaozhou and its nearby civilian ship trading ports. ${ }^{10}$ After the industrialization of many industries, many peasants poured into the cities. The peasant and citizen classes were transformed into the working class because of the establishment of factories. In Yantai, for example, the total population increased nearly tenfold in the decade from 1882 to 1892 , and by 1919 the urban population of Yantai was nearly 150,000. At the same time, domestic and foreign capital also to these areas concentrated in the market stimulation, originally only a farming side industry cocoon and silk industry ushered in a major explosion, exports to the United Kingdom, the United States, France, Italy, Japan, and many other countries, and prices rose year after year. Foreign machinery reeling, silk weaving technology was also introduced to Yantai and other coastal cities in Shandong Province, greatly improving its quality and efficiency, weaving pongee in line with international standards, hot overseas sales. At that time, mulberry silk in the global competition, and the pongee market was almost monopolized by China, became the hope of modern China's textile industry.

\section{Conclusion}

The concept of pongee formed in Shandong at the end of the 19th century, its formation is not a single reason. The formation and development of pongee in Shandong is the result of a variety of factors interacting with each other. Shandong has a long history of silk reeling and silk weaving; silk weaving has always been a civilian to supplement the agricultural economy. The suitable terrain and climate in the mountainous region of southwestern Shandong made the food of the sericulture - sericulture tree is abundant, coupled with the government and officials of the Qing Dynasty on the vigorous dissemination of stockbreeding techniques, the abundance of raw materials make the production of pongee in large quantities possible. With the impact of the world industrial revolution, several important ports along the coast of Shandong and international trade, advanced silk weaving machinery and technology was introduced, opening up the international market of shantung, from then on the reputation at home and abroad, become an important industry in modern China's export trade and loud Chinese business card.

\section{References}

1 (Han) Ban Gu, Hanshu. Geography.

2 A Commentary on the Manuscript of the Qing Dynasty History (1999, Book 12, Vol. 333: The One Hundred and Thirteen Biographies). Beijing: The Commercial Press.

3 (Qing) Shu Kong'an, Wang Houdi. (Qing) Shu Kong'an, Wang Houdi. Ninghai zhi-vol. 12: Officials. Tongzhi 3 years engraved book.

4 Zhang, K. (1982). The origin and spread of sericulture in China. Sericulture Science, (2).

5 Table: Statistics of articles and books related to sericulture written by intellectuals in Shandong during the Qing Dynasty. (1984). The earliest book on sericulture was "The Method of Raising Mountain Silkworms". Sericulture Science, (3).

${ }^{6} \mathrm{Wu}, \mathrm{Q}$. (2016). The publication, dissemination and influence of sericulture books in the Ming and Qing dynasties. Local Cultural Studies, (2), 34-41.

7 Xu, T. (1995). The development of Shandong economy in the Ming and Qing dynasties. Studies in Chinese economic history, (3), 42-65.

8 (Ming) Wu Weiye. (1990). The complete works of Wu Meicun (Vol. 16). Shanghai: Shanghai Ancient Books Publishing House. Post-Poem Collection VIII.

9 (Qing) Han Mengzhou, Yang Hongjiang and Huade Gong. (1983). Three books on the sericulture. Beijing: Agricultural Press.

10 Zhuang, W. M. Changes in the structure of the geographical distribution of merchants' capital in Shandong in modern times and its effects. Journal of Qilu Studies, (4), 108-114.

\section{Copyrights}

Copyright for this article is retained by the author(s), with first publication rights granted to the journal.

This is an open-access article distributed under the terms and conditions of the Creative Commons Attribution license (http://creativecommons.org/licenses/by/4.0/). 